\title{
Concurrent Graves' Disease and TSH Secreting Pituitary Adenoma Presenting Suppressed Thyrotropin Levels: A Case Report and Review of the Literature
}

\author{
Jinrong $\mathrm{Fu}^{1}$, Anhua $\mathrm{Wu}^{2}$, Xiaoli Wang ${ }^{1 *}$ and Haixia Guan ${ }^{1,3 *}$ \\ ${ }^{1}$ Department of Endocrinology and Metabolism, Institute of Endocrinology, The First Hospital of China Medical University, \\ Shenyang, China, ${ }^{2}$ Department of Neurosurgery, The First Hospital of China Medical University, Shenyang, China, \\ ${ }^{3}$ Department of Endocrinology, Guangdong Provincial People's Hospital, Guangdong Academy of Medical Science, \\ Guangzhou, China
}

\section{OPEN ACCESS}

Edited by:

Hidenori Fukuoka,

Kobe University, Japan

Reviewed by:

Fumio Otsuka,

Okayama University, Japan

Hiraku Kameda,

Cedars Sinai Medical Center,

United States

${ }^{*}$ Correspondence:

Xiaoli Wang

wlittlepear@163.com

Haixia Guan

hxguan@vip.126.com

Specialty section: This article was submitted to

Pituitary Endocrinology,

a section of the journal

Frontiers in Endocrinology

Received: 05 April 2020

Accepted: 29 June 2020

Published: 06 August 2020

Citation:

Fu J, Wu A, Wang X and Guan H (2020) Concurrent Graves' Disease and TSH Secreting Pituitary Adenoma

Presenting Suppressed Thyrotropin Levels: A Case Report and

Review of the Literature.

Front. Endocrinol. 11:523.

doi: $10.3389 /$ fendo.2020.00523
Background: Thyroid stimulating hormone (TSH) secreting pituitary adenoma (TSHoma) is a rare cause of hyperthyroidism. To date there have been only thirteen cases reporting the coexistence of TSHoma with Graves' disease (GD). The diagnosis and management for such hyperthyroidism due to both etiologies remain challenging.

Case Report: A 55-year-old Chinese female presented with signs and symptoms of thyrotoxicosis. Thyroid function tests showed elevated thyroid hormones and mildly suppressed TSH values. Her anti-thyrotropin receptor antibody (TRAb) was positive. Octreotide suppression test successfully decreased her TSH. Magnetic resonance imaging showed a pituitary macroadenoma. She underwent endoscopic trans-sphenoidal resection and surgical pathology confirmed a TSH producing pituitary adenoma. Methimazole was prescribed after surgery and her clinical course was monitored.

Conclusions: Here we report a case of a 55-year-old female with TSHoma and Graves' disease whose TSH level was mildly suppressed. This case emphasizes the importance of thoroughly evaluating the thyroid function test during the diagnosis of hyperthyroidism. It also highlights the challenges in the diagnosis and treatment of this rare condition.

Keywords: TSH secreting pituitary adenoma, TSHoma, Graves' disease, concomitant, thyrotropin

\section{INTRODUCTION}

Hyperthyroidism is a pathological disorder caused by excess thyroid hormone synthesis and secretion from the thyroid gland. Graves' disease (GD) is the most common cause of hyperthyroidism, characterized by unregulated stimulation of the TSH receptor by autoreactive TSH receptor antibodies (TRAb) (1). A rare etiology of hyperthyroidism is thyroid stimulating hormone (TSH) secreting pituitary adenoma (TSHoma), with the prevalence of 1-2 cases per million. Diagnosis of TSHoma should be considered when thyroid hormone levels increased without a suppressed TSH concentration, a condition referred to as SITSH (syndrome of inappropriate secretion of thyrotropin) (2). The concurrent of GD and TSHoma is rare. Here we 
report a case of GD and TSHoma with suppressed TSH levels, in which the coexistence of TSHoma could be easily misdiagnosed.

\section{CASE DESCRIPTION}

A 55-year-old Chinese female initially presented to our hospital in May 2019, complaining about 2-month history of thermophobia, anxiety, palpitation, hyperdefecation and weight loss. She denied other symptoms including headache, visual field defect or galactorrhea. She denied intakes of biotin and other medications. Physical examination showed that her body mass index was $22.8 \mathrm{~kg} / \mathrm{m}^{2}$, blood pressure was $150 / 72 \mathrm{mmHg}$, and pulse was $110 \mathrm{bpm}$. The patient had mild upper eyelid retraction but no exophthalmos was observed. She had moist skin, tremors of hands and tongue, and a grade I goiter with soft texture. The patient had undergone hysterectomy for uterine leiomyomas 10 years ago. She denied family history of relevant disease including thyroid disease, pituitary disease, hypertension, coronary heart disease and diabetes mellitus.

Thyroid function test (Abbott, USA) showed $\mathrm{FT}_{3} 39 \mathrm{pmol} / \mathrm{l}$ (normal range, 2.63-5.7 pmol/l), $\mathrm{FT}_{4} 51.07 \mathrm{pmol} / \mathrm{l}$ (9.01-19.05 pmol/l) wisth TSH $0.337 \mathrm{mIU} / \mathrm{l}(0.35-4.94 \mathrm{mIU} / \mathrm{l}$; intraassay coefficient of variation $<6 \%)$. Her thyroid peroxidase antibodies (Abbott) and thyroglobulin antibodies (Abbott) were $1.56 \mathrm{IU} / \mathrm{ml}$ $(0-5.61 \mathrm{IU} / \mathrm{ml})$ and $197.7 \mathrm{IU} / \mathrm{ml}(0-4.11 \mathrm{IU} / \mathrm{ml})$. Her TRAb (Roche, Switzerland), TSAb (Siemens Healthcare, Llanberis, $\mathrm{UK})$ and thyroglobulin levels were $5.63 \mathrm{IU} / \mathrm{l}(0-1.75 \mathrm{IU} / \mathrm{l}), 4.7$ IU/1 (0-0.55 IU/l) and $56.6 \mathrm{ng} / \mathrm{ml}(1.6-59.9 \mathrm{ng} / \mathrm{ml})$, respectively. Re-examination 1 week later showed $\mathrm{FT}_{3} 25.23$ pmol/l, $\mathrm{FT}_{4}$ $39.25 \mathrm{pmol} / \mathrm{l}$ and TSH $0.2595 \mathrm{mIU} / \mathrm{l}$. Similar results were obtained from different laboratories (Roche, Switzerland and Siemens, Germany). The mildly suppressed TSH levels were neither consistent with the condition of Graves' hyperthyroidism nor SITSH. Her blood test showed low level of neutrophils (Table 1). Thus, she was prescribed on propranolol and low iodine diet for symptomatic control and recommended for further assessments.

Further assessments showed that sex hormone-binding globulin (SHBG) was elevated (158 nmol/l; 18-114 nmol/l). Her ACTH and growth hormone were normal, LH and FSH levels were concordant with her age (Table 1). After 24-h subcutaneous injection of octreotide ( $0.1 \mathrm{mg}$ s.c.), TSH decreased from 0.11 to $0.04 \mathrm{mIU} / \mathrm{l}$, the suppression ratio of TSH at 24 vs. $0 \mathrm{~h}$ was $63 \%$. TRH stimulation was not performed due to unavailability of TRH in China. Mutations of the TSH receptor and thyroid hormone receptor $\beta$ (THRB) genes were not identified.

Magnetic resonance imaging (MRI) displayed a less enhanced area in the sella $(17 \times 15 \mathrm{~mm})$, involving the cavernous sinuses (Figures 1A,B). Increased blood flow in the thyroid was detected in ultrasound, with a nodule (ACR TR 3) located in the left lobe (Figure 1D). Radionuclide scan $\left({ }^{99} \mathrm{mTcO}_{4}\right)$ showed diffusely increased uptake (Figure 1E). Computer tomography scan (CT) showed normal adrenal glands.

Based on clinical and biochemical evidence for hyperthyroidism, low but incompatibly suppressed TSH, elevated TRAb, TSH suppression by octreotide, and the MRI finding, a diagnosis of TSHoma with concomitant GD was highly suspected.
TABLE 1 | Preoperative and postoperative results of baseline laboratory tests and hormone profiles.

\begin{tabular}{|c|c|c|c|}
\hline Parameter & Preoperative & Postoperative & Reference range \\
\hline \multicolumn{4}{|c|}{ Baseline laboratory tests } \\
\hline WBC & 4.10 & 7.00 & $3.50-9.50 \times 10^{9} / \mathrm{L}$ \\
\hline Neutrophil & 0.78 & 3.54 & $1.80-6.30 \times 10^{9} / \mathrm{L}$ \\
\hline Lymphocyte & 2.82 & 2.93 & $1.10-3.20 \times 10^{9} / \mathrm{L}$ \\
\hline HGB & 132 & 124 & $115-150 \mathrm{~g} / \mathrm{L}$ \\
\hline $\mathrm{RBC}$ & 3.99 & 4.45 & $3.80-5.10 \times 10^{12} / \mathrm{L}$ \\
\hline PLT & 178 & 299 & $125-350 \times 10^{9} / L$ \\
\hline $\mathrm{K}^{+}$ & 3.19 & 3.89 & $3.50-5.30$ mmol/L \\
\hline $\mathrm{Na}^{+}$ & 146.8 & 144.9 & $137.0-147.0 \mathrm{mmol} / \mathrm{L}$ \\
\hline AST & 28 & 21 & 13-35 (U/L) \\
\hline ALT & 33 & 31 & $7-40(\mathrm{U} / \mathrm{L})$ \\
\hline GGT & 106 & 141 & $7-45(U / L)$ \\
\hline TP & 24 & 44 & 65-85 (g/L) \\
\hline ALB & 16.1 & 15.8 & 40-55 (g/L) \\
\hline TBA & 2 & 1 & 0-10 (umol/L) \\
\hline TBIL & 13 & 7.3 & 3.4-20.5 (umol/L) \\
\hline Urea & 5.82 & 4.25 & 2.85-7.14 (mmol/L) \\
\hline $\mathrm{Cr}$ & 32 & 34 & 45-84 (umol/L) \\
\hline Cys-C & 1.21 & 1.33 & $0.53-0.95$ (mg/L) \\
\hline \multicolumn{4}{|c|}{ Hormone profiles } \\
\hline ACTH & 37.76 & 33.59 & 7.2-63.3 (pg/ml) \\
\hline Cortisol & 489.9 & 406.9 & $\begin{array}{l}\text { Morning: } 171-536 \mathrm{nmol} / \mathrm{L} \\
\text { Afternoon: } 64-327 \mathrm{nmol} / \mathrm{L}\end{array}$ \\
\hline $\mathrm{GH}$ & 0.32 & 0.88 & $0.05-8$ ug/L \\
\hline$P R L$ & 265 & 74.8 & 40-530 mlU/L \\
\hline IGF-1 & 108 & 112 & 75-238 ng/ml \\
\hline LH & 21.3 & 17.5 & 11.3-39.8 mlU/mL \\
\hline $\mathrm{FSH}$ & 57 & 53 & $21.7-153$ mlU/mL \\
\hline
\end{tabular}

WBC, white blood cell; HGB, hemoglobin; RBC: red blood cell; PLT, platelet; $\mathrm{Na}^{+}$, sodium; $\mathrm{K}^{+}$, potassium; $A S T$, aspartate transaminase; $A L T$, alanine transaminase; GGT, gamma-glutamyl transferase; TP, total protein; ALB, albumin; TBA, total bile acid; TBIL, total bilirubin; $\mathrm{Cr}$, creatinine; Cys-C, Cystatin C; ACTH, adrenocorticotropin; $\mathrm{GH}$, growth hormone; PRL, prolactin; IGF-1, Insulin-like growth factor-1; LH, Luteinizing hormone; FSH, Follicle stimulating hormone.

In July 2019, the pituitary mass was removed through the endoscopic trans-sphenoidal resection. To prevent thyroid storm, the patient was treated with propranolol pre-operation, and we made thorough preparation with a team of experienced neurosurgeons, endocrinologists and unit of anesthesia and intensive care. The patient experienced an uneventful surgery and postoperative recovery. Surgical pathology assessment confirmed a pituitary macroadenoma. Immunohistochemistry showed positive staining for TSH (mouse monoclonal to TSH, Thermo Fisher Scientific, Fremont, CA, USA) (Figure 1F), whereas negative staining for ACTH, GH or PRL. The percentage of positive Ki-67 was $1 \%$. Serum TSH was $0.001 \mathrm{mIU} / \mathrm{l}$ at 1 week after the surgery. These findings confirmed the presence of TSHoma.

After surgery, her symptoms got alleviated but did not vanish. The patient did not have exophthalmos after surgery. Postoperation follow-up at 1 month showed that her $\mathrm{FT}_{3}$ was 19.71 $\mathrm{pmol} / \mathrm{l}, \mathrm{FT}_{4}$ was $30.72 \mathrm{pmol} / \mathrm{l}$, TSH was $0.0765 \mathrm{mIU} / \mathrm{l}$, TRAb was $6.11 \mathrm{IU} / \mathrm{l}$ and TSAb was $5.58 \mathrm{IU} / \mathrm{l}$ (Figure 2). This was supportive 


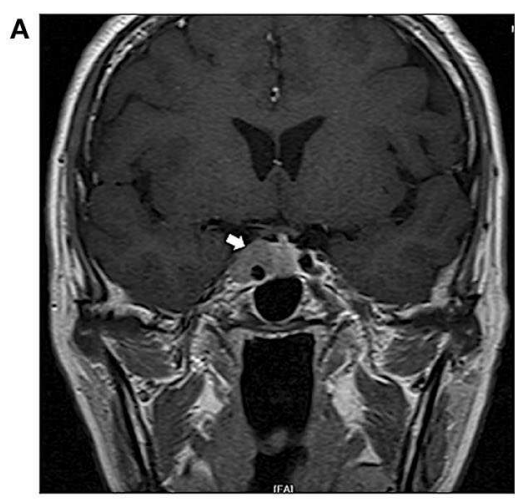

D

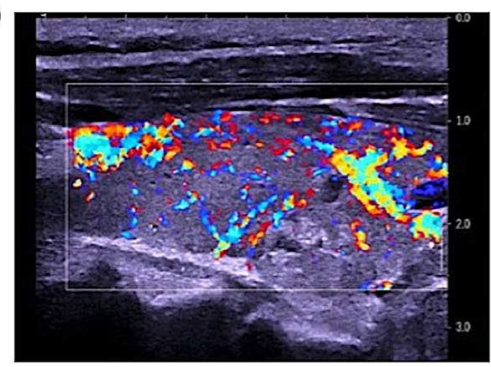

B

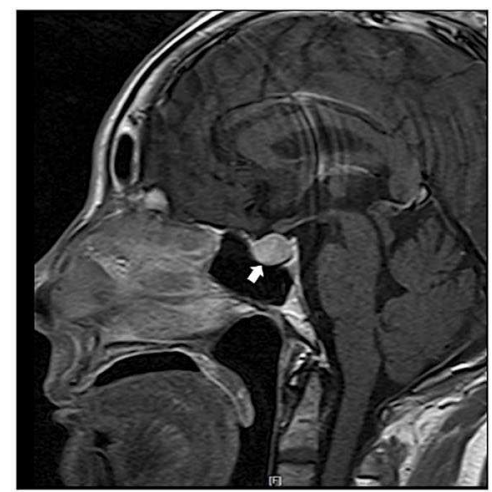

E

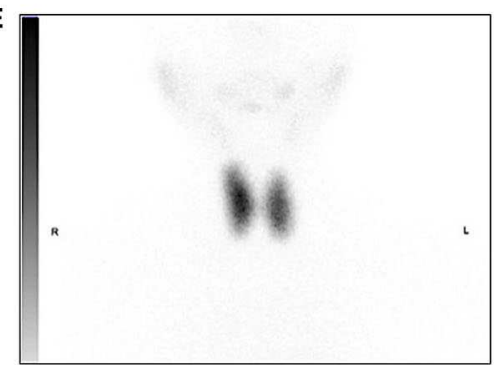

C

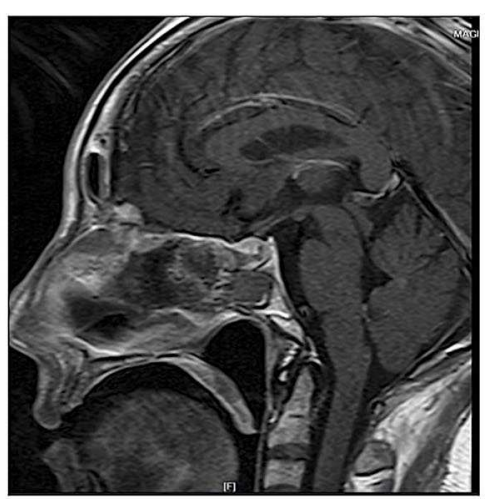

$\mathbf{F}$

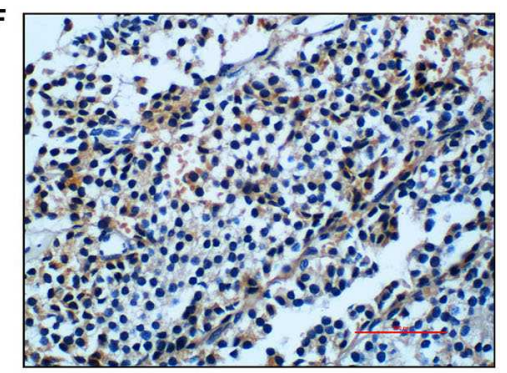

FIGURE 1 | Radiology imaging of the patient and immunostaining for TSH in the pituitary tumor. (A) Preoperative magnetic (MR) resonance image (T1-weight, sagittal view). White arrow pointing to a less enhanced area in the sella $(17 \times 15 \mathrm{~mm}$, arrow), involving the cavernous sinuses. (B) Preoperative magnetic (MR) resonance image (T1-weight, coronal view). (C) Postoperative MR image (T1-weight, sagittal view). (D) Thyroid ultrasound revealed a heterogenous parenchyma with rich blood flow and a nodule (ACR TR 3) located in the left lobe. The right thyroid lobe measures $5.00 \times 1.70 \times 1.87 \mathrm{~cm}$. The thyroid isthmus measures $0.23 \mathrm{~cm}$ in AP dimension. The left thyroid lobe measures $5.08 \times 1.77 \times 1.97 \mathrm{~cm}$. (E) Radionuclide $\left({ }^{99} \mathrm{mTcO}_{4}\right)$ scan showed diffusely increased uptake, the ratio of uptake of the tracer in the thyroid to that in the background was 45 (right lobe) and 40 (left lobe). (F) Positive immunostainning for TSH in the pituitary tumor (magnification $400 \times$ ).

for an untreated GD. She was prescribed on methimazole 15 $\mathrm{mg} /$ day and propranolol $47.5 \mathrm{mg} /$ day. In December 2019, she reported $4 \mathrm{~kg}$-weight gain and improved symptoms. Her $\mathrm{FT}_{3}$ and $\mathrm{FT}_{4}$ decreased to 8.34 and $23.79 \mathrm{pmol} / \mathrm{l}$, respectively, and TSH increased to $0.1258 \mathrm{mIU} / \mathrm{l}$ (Figure 2). TRAb and TSAb was declined to 3.57 and $1.45 \mathrm{IU} / \mathrm{l}$. The MRI did not show any sign of tumor regrowth (Figure 1C). She remained on methimazole 15 $\mathrm{mg} /$ day and was followed up.

\section{DISCUSSION}

TSHoma is a rare disease accounting for $0.5-3 \%$ of all functioning pituitary tumors (3). The first case of TSHoma was reported in 1960 (4). Clinical features of TSHoma are often characterized by mild signs and symptoms of thyrotoxicosis and neurological symptoms caused by the compression of pituitary mass (2). The diagnosis of TSHoma is usually based on the biochemical findings of SITSH, histochemical and imaging evidence. SHBG and THR $\beta$ mutation should be examined to exclude the possibility of RTH.

TSHoma complicated by GD is extremely rare. There have been only 13 cases reported so far (Table 2) (5-16). Among them, six cases were found the coexistence of TSHoma and GD upon the initial diagnosis $(6,9,13-16)$. Majority of these cases presented normal to elevated TSH with increased thyroid hormones, which was suggestive of SITSH, therefore the possibility of TSHoma was checked. In the present case, repeated TSH measurements were below the normal range. Given her predominant manifestations of thyrotoxicosis and positive TRAb, the condition could be easily misdiagnosed as GD alone. Nonetheless, keeping in mind that the TSH level in untreated overt GD is normally suppressed to below $0.1 \mathrm{mU} / \mathrm{l}$ by negative feedback due to obviously elevated thyroid hormones, we identified the hint for her unusual etiology of hyperthyroidism. We suspected the possibility of coexistent central hyperthyroidism instead of initiating antithyroid medication. Further investigation and surgical pathology confirmed our diagnosis.

Whether it is an incidental coexistence of TSHoma with GD or there is a mechanism that connects TSHoma and GD remained to be elucidated. Both the continuous elevation or fluctuation of TSH might induce the production of anti-idiotypic antibodies, or regulate Fas-mediated apotosis against the thyroid gland, leading to $\operatorname{GD}(8,9)$. More evidence is needed to confirm the association between GD and TSHoma.

TSHoma is characterized by expression of somatostatin receptors (SSTRs), especially SSTR2 and SSTR5. Administration of long acting somatostatin analogs such as octreotide for at least 2 months is useful in the differential diagnosis of central hyperthyroidism, as well as the treatment of TSHoma (17). One case also reported successful treatment of TSHoma with pasireotide, as an alternative somatostatin analog (18). A recent 


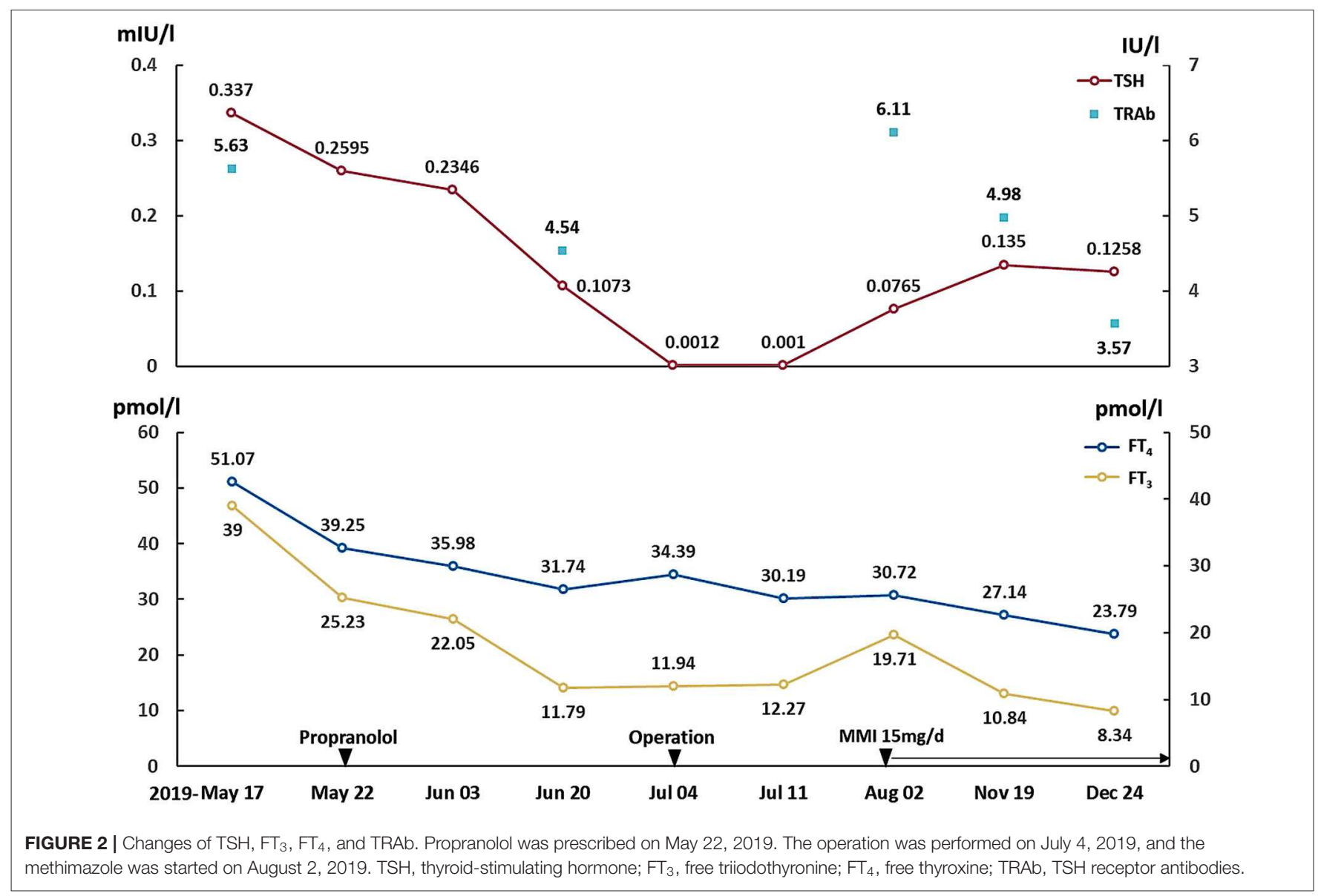

study suggested that somatostatin analog (SSA) suppression test was able to diagnose TSHoma with a positive predictive value of $88.89 \%$. The test also showed good performance in distinguishing RTH and TSHoma without imaging evidence, which is valuable for medical centers unable to conduct mutation analysis (19). This suppression would be easily recognized if the basal TSH is normal or high. The present report, for the first time, presented the effect of octreotide on the diagnosis of TSHoma and GD with slightly suppressed TSH level.

As we all know, the treatment of TSHoma is very different from that of GD. Thus, it is challenging to treat TSHoma concomitant GD. We noticed in previous cases, using antithyroid drugs as the first-choice treatment led to the risk of deterioration of thyroid function $(8,11,12,15)$. It is not surprising as antithyroid drugs might increase the level of TSH by inhibiting the negative feedback, thus stimulating the growth of TSHoma. Besides, the patient showed low neutrophil levels before surgery, which is the contradiction of antithyroid drugs. Hence, we prescribed beta-receptor blocker instead of methimazole before her neurosurgery. Indeed, based on the patient's positive result of octreotide suppression test, we had considered to use long-acting form of somatostatin analogs pre-operatively as the medication might relive her symptoms of hyperthyroidism and shrinking the size of pituitary tumor (3), but the patient refused due to its high cost.

Interestingly, the patient showed temporary remission after taking propranolol. There were two possible explanations suspected. First, the level of TSH secreted by TSHoma is fluctuating, which might occur even without medication. The decreased TSH led to decreased $\mathrm{FT}_{3}$ and $\mathrm{FT}_{4}$. Second, propranolol inhibits the conversion from $\mathrm{T}_{4}$ to $\mathrm{T}_{3}$ (20), therefore it might exert some beneficial effects in thyrotoxicosis (21). The combination of low iodine diet and propranolol was effective in controlling the hyperthyroidism of our patient in a short time, which could be inspiration in the management of patients like this case.

In this challenging case, we failed to normalize the thyroid function of the patient pre-operatively. Even though thyroid storm is rarely reported in pituitary surgery (2), we did thorough plan with a multidisciplinary team to prevent this event. After surgery, we initiated methimazole treatment for her persistent GD and kept watching her clinical manifestation, thyroid function and pituitary imaging.

Limitations in this report include: First, we did not detect the level of $\alpha$-TSH. Elevated FSH level was common for postmenopausal women, which may interfere with the detection of TSH (22). Unfortunately, we were unable to perform this test 
TABLE 2 | Case reports of patients with GD and TSHoma.

\begin{tabular}{|c|c|c|c|c|c|c|c|c|}
\hline References & Country & $\begin{array}{c}\text { Age/ } \\
\text { gender }\end{array}$ & Clinical presentation & $\begin{array}{c}\text { TSH } \\
(\mathrm{mlU} / \mathrm{L})\end{array}$ & $\begin{array}{l}\text { Pituitary } \\
\text { tumor size } \\
\text { (mm) }\end{array}$ & Clinical course & Treatment & $\begin{array}{l}\text { Follow up of } \\
\text { TSHoma }\end{array}$ \\
\hline $\begin{array}{l}\text { O'Donnell } \\
\text { et al. (5) }\end{array}$ & UK & $25 / \mathrm{M}$ & $\begin{array}{l}\text { Signs of thyrotoxicosis, } \\
\text { peripheral vision defect }\end{array}$ & 28 & $\mathrm{~N} / \mathrm{A}$ & TSHoma $\rightarrow$ GD & $\begin{array}{l}\text { Cortisol, testosterone, } \\
\text { antithyroid drug, thyroxine, } \\
\text { hypophysectomy }\end{array}$ & $\begin{array}{l}\text { TSH remained } \\
\text { undetectable }\end{array}$ \\
\hline Sandler (6) & USA & $56 / F$ & $\begin{array}{l}\text { Signs of thyrotoxicosis, } \\
\text { acromegaly, } \\
\text { symptomatic } \\
\text { ophthalmopathy }\end{array}$ & 8.1 & $\mathrm{~N} / \mathrm{A}$ & $\begin{array}{l}\text { GD complicated } \\
\text { with TSHoma }\end{array}$ & $\begin{array}{l}\text { Antithyroid drug, cortisone, } \\
\text { pituitary irradiation, } \\
\text { radioiodine therapy }\end{array}$ & $\begin{array}{l}\text { Recurrence of } \\
\text { hyperthyroidism }\end{array}$ \\
\hline Azukizawa (7) & $\mathrm{N} / \mathrm{A}$ & $\mathrm{N} / \mathrm{A}$ & $\mathrm{N} / \mathrm{A}$ & N/A & $\mathrm{N} / \mathrm{A}$ & TSHoma $\rightarrow$ GD & N/A & $\mathrm{N} / \mathrm{A}$ \\
\hline Kamoi et al. (8) & Japan & $46 / F$ & $\begin{array}{l}\text { Signs of thyrotoxicosis } \\
\text { and galactorrhoea }\end{array}$ & 15.5 & $\mathrm{~N} / \mathrm{A}$ & TSHoma $\rightarrow$ GD & $\begin{array}{l}\text { Antithyroid drug, } \\
\text { prednisolone, } \\
\text { transsphenoidal surgery }\end{array}$ & $\begin{array}{l}\text { Recurrence of } \\
\text { hyperthyroidism }\end{array}$ \\
\hline $\begin{array}{l}\text { Koriyama et al. } \\
\text { (9) }\end{array}$ & Japan & $31 / F$ & Signs of thyrotoxicosis & 2.1 & $\mathrm{~N} / \mathrm{A}$ & $\begin{array}{l}\text { GD complicated } \\
\text { with TSHoma }\end{array}$ & $\begin{array}{l}\text { Octreotide and } \\
\text { levothyroxine sodium, } \\
\text { antithyroid drug, } \\
\text { transsphenoidal surgery } \\
\text { (twice) }\end{array}$ & $\begin{array}{l}\text { Discontinue } \\
\text { treatment for } \\
\text { financial reasons }\end{array}$ \\
\hline $\begin{array}{l}\text { Kageyama } \\
\text { et al. (10) }\end{array}$ & Japan & $21 / F$ & Signs of thyrotoxicosis & 3.16 & 10 & TSHoma $\rightarrow$ GD & Transsphenoidal surgery & $\mathrm{N} / \mathrm{A}$ \\
\hline Lee et al. (11) & China & $27 / \mathrm{M}$ & Signs of thyrotoxicosis & 0.004 & 10.4 & $\mathrm{GD} \rightarrow \mathrm{TSHoma}$ & $\begin{array}{l}\text { Antithyroid drug, } \\
\text { transsphenoidal surgery }\end{array}$ & $\mathrm{N} / \mathrm{A}$ \\
\hline Lee et al. (11) & China & $28 / F$ & Signs of thyrotoxicosis & 0.123 & 15 & $\mathrm{GD} \rightarrow \mathrm{TSHoma}$ & Antithyroid drug & $\mathrm{N} / \mathrm{A}$ \\
\hline $\begin{array}{l}\text { Ogawa et al. } \\
(12)\end{array}$ & Japan & $32 / F$ & Signs of thyrotoxicosis & $\begin{array}{l}\text { Less than } \\
\text { detectable }\end{array}$ & 5 & $\mathrm{GD} \rightarrow \mathrm{TSHoma}$ & $\begin{array}{l}\text { Antithyroid drug, } \\
\text { transsphenoidal surgery }\end{array}$ & Recovery \\
\hline $\begin{array}{l}\text { Kamoun et al. } \\
\text { (13) }\end{array}$ & France & $36 / F$ & $\begin{array}{l}\text { Signs of thyrotoxicosis, } \\
\text { exophthalmos }\end{array}$ & $1.2-1.8$ & 10 & $\begin{array}{l}\text { GD complicated } \\
\text { with TSHoma }\end{array}$ & $\begin{array}{l}\text { Antithyroid drug, lanreotide, } \\
\text { thyroid lobectomy, } \\
\text { transsphenoidal surgery }\end{array}$ & Recovery \\
\hline $\begin{array}{l}\text { Okuyucu et al. } \\
\text { (14) }\end{array}$ & Turkey & $37 / F$ & $\begin{array}{l}\text { Signs of thyrotoxicosis, } \\
\text { goiter and } \\
\text { exophthalmos }\end{array}$ & 5.54 & 13 & $\begin{array}{l}\text { GD complicated } \\
\text { with TSHoma }\end{array}$ & $\begin{array}{l}\text { Thyroidectomy, } \\
\text { transsphenoidal surgery }\end{array}$ & $\mathrm{N} / \mathrm{A}$ \\
\hline Arai et al. (15) & Japan & $40 / F$ & Signs of thyrotoxicosis & 0.27 & 13 & $\begin{array}{l}\text { GD complicated } \\
\text { with TSHoma }\end{array}$ & $\begin{array}{l}\text { Antithyroid drug, } \\
\text { transsphenoidal surgery }\end{array}$ & Recovery \\
\hline Li et al. (16) & China & $55 / \mathrm{M}$ & $\begin{array}{l}\text { Signs of thyrotoxicosis, } \\
\text { recurrent atrial } \\
\text { fibrillation }\end{array}$ & 8.9 & 23 & $\begin{array}{l}\text { GD complicated } \\
\text { with TSHoma }\end{array}$ & $\begin{array}{l}\text { Antithyroid drug, } \\
\text { transsphenoidal surgery }\end{array}$ & $\begin{array}{l}\text { Recurrence of } \\
\text { TSHoma }\end{array}$ \\
\hline Present case & China & $55 / F$ & Signs of thyrotoxicosis & 0.337 & 17 & $\begin{array}{l}\text { GD complicated } \\
\text { with TSHoma }\end{array}$ & $\begin{array}{l}\text { Transsphenoidal surgery, } \\
\text { antithyroid drug }\end{array}$ & Recovery \\
\hline
\end{tabular}

F, Female; M, male; GD, Graves' disease; N/A, Not available.

due to the unavailability of the test kit of alpha-subunits. Second, we did not perform the TRH stimulation test limited by detection methods, therefore the information relating to HPA axis function was inadequate. Alternatively, we tested pituitary hormones both before and after surgery and the results were normal. Third, the expression of SSTR2/SSTR5, which was useful in deciding whether SSA can be potential treatment, was not examined in this case. This examination is not a routine test in our hospital, so we did the octreotide suppression test instead, which indicated that SSA might be useful in reducing the growth and treating the recurrence of TSHoma.

In conclusion, this report described a patient who had clear biochemical and clinical features of hyperthyroidism with mildly suppressed TSH levels. Further investigations revealed the dual presence of TSHoma and GD. This case reminds clinicians that careful interpretation of thyroid function test is important during the diagnosis of hyperthyroidism. It also highlights the challenges in the diagnosis and treatment of this rare condition.

\section{ETHICS STATEMENT}

Written informed consent was obtained from the individual for the publication of any potentially identifiable images or data included in this article.

\section{AUTHOR CONTRIBUTIONS}

HG and XW designed the study, collected data, and managed the patients. JF prepared the manuscript and figures. AW operated on and followed up the patient. HG revised the manuscript. All authors contributed to the article and approved the submitted version.

\section{FUNDING}

This work was supported by the National Natural and Science Foundation of China (grant number: 81870538). 


\section{REFERENCES}

1. De Leo S, Lee SY, Braverman LE. Hyperthyroidism. Lancet. (2016) 388:90618. doi: 10.1016/S0140-6736(16)00278-6

2. Beck-Peccoz P, Giavoli C, Lania A. A 2019 update on TSHsecreting pituitary adenomas. J Endocrinol Invest. (2019) 42:14016. doi: 10.1007/s40618-019-01066-X

3. Beck-Peccoz P, Lania A, Beckers A, Chatterjee K, Wemeau JL. 2013 European thyroid association guidelines for the diagnosis and treatment of thyrotropin-secreting pituitary tumors. Eur Thyroid J. (2013) 2:7682. doi: $10.1159 / 000351007$

4. Jailer JW, Holub DA. Remission of Graves' disease following radiotherapy of a pituitary neoplasm. Am J Med. (1960) 28:497-500. doi: 10.1016/0002-9343(60)90181-9

5. O'Donnell J, Hadden DR, Weaver JA, Montgomery DAD. Thyrotoxicosis recurring after surgical removal of a thyrotrophin-secreting pituitary tumour. Proc R Soc Med. (1973) 66:441-2. doi: 10.1177/003591577306600511

6. Sandler R. Recurrent hyperthyroidism in an acromegalic patient previously treated with proton beam irradiation: Graves' disease as probable etiology based on follow-up observations. J Clin Endocrinol Metab. (1976) 42:1638. doi: 10.1210/jcem-42-1-163

7. Azukizawa M MS, Miyai K, Miki T, Yabu Y, Amino N. TSH producing pituitary adenoma associated with Graves' disease. In: Stockigt JR, Nagataki S, editors. Thyroid Research, Vol VII. Canberra: Australian Academy of Science (1980). p. 645-8.

8. Kamoi K, Mitsuma T, Sato H, Yokoyama M, Washiyama K, Tanaka R, et al. Hyperthyroidism caused by a pituitary thyrotrophin-secreting tumour with excessive secretion of thyrotrophin-releasing hormone and subsequently followed by Graves' disease in a middle-aged woman. Acta Endocrinol. (1985) 110:373-82. doi: 10.1530/acta.0.1100373

9. Koriyama N, Nakazaki M, Hashiguchi H, Aso K, Ikeda Y, Kimura T, et al. Thyrotropin-producing pituitary adenoma associated with Graves' disease. Eur J Endocrinol. (2004) 151:587-94. doi: 10.1530/eje.0.1510587

10. Kageyama. K, Ikeda. H, Sakihara. S, Nigawara. T, Terui K, Tsutaya. S, et al. A case of thyrotropin-producing pituitary adenoma, accompanied by an increase in anti-thyrotropin receptor antibody after tumor resection. $J$ Endocrinol Invest. (2007) 30:957-61. doi: 10.1007/BF03349244

11. Lee MT, Wang CY. Concomitant Graves hyperthyroidism with thyrotrophin-secreting pituitary adenoma. South Med J. (2010) 103:347-9. doi: 10.1097/SMJ.0b013e3181d3ce93

12. Ogawa Y, Tominaga T. Thyroid-stimulating hormone-secreting pituitary adenoma presenting with recurrent hyperthyroidism in post-treated Graves' disease: a case report. J Med Case Rep. (2013) 7:27. doi: 10.1186/1752-1947-7-27

13. Kamoun M, d'Herbomez M, Lemaire C, Fayard A, Desailloud R, Huglo $\mathrm{D}$, et al. Coexistence of thyroid-stimulating hormone-secreting pituitary adenoma and graves' hyperthyroidism. Eur Thyroid J. (2014) 3:604. doi: 10.1159/000355386

14. Okuyucu K, Alagoz E, Arslan N, Taslipinar A, Deveci MS, Bolu E. Thyrotropinoma with Graves' disease detected by the fusion of indium-111 octreotide scintigraphy and pituitary magnetic resonance imaging. Indian J Nucl Med. (2016) 31:141-3. doi: 10.4103/0972-3919. 178322

15. Arai N, Inaba M, Ichijyo $T$, Kagami H, Mine Y. Thyrotropin-producing pituitary adenoma simultaneously existing with Graves' disease: a case report. J Med Case Rep. (2017) 11:9. doi: 10.1186/s13256-016-1172-4

16. Li J, Tan H, Huang J, Luo D, Tan Y, Yu R, et al. Case report of recurrent atrial fibrillation induced by thyrotropin-secreting pituitary adenoma with Graves' disease. Medicine. (2018) 97:e11047. doi: 10.1097/MD.0000000000 011047

17. Mannavola D, Persani L, Vannucchi G, Zanardelli M, Fugazzola L, Verga U, et al. Different responses to chronic somatostatin analogues in patients with central hyperthyroidism. Clin Endocrinol. (2005) 62:17681. doi: 10.1111/j.1365-2265.2004.02192.x

18. van Eersel MEA, Meeuwisse-Pasterkamp SH, Muller Kobold AC, Meiners LC, den Dunnen WF, Hofland LJ, et al. Treatment of a thyrotropin-secreting pituitary adenoma (TSH-oma) with pasireotide LAR. Clin Endocrinol. (2017) 87:877-9. doi: 10.1111/cen.13431

19. Han R, Shen L, Zhang J, Xie J, Fang W, Sun Q, et al. Diagnosing thyrotropinsecreting pituitary adenomas by short-term somatostatin analogue test. Thyroid. (2020). doi: 10.1089/thy.2019.0470. [Epub ahead of print].

20. Theilade. P, Hansen. JM, Skovsted. L, Faber. J, Kirkegård. C, Friis. T, et al. Propranolol influences serum T3 and reverse T3 in hyperthyroidism. Lancet. (1977) 2:363. doi: 10.1016/S0140-6736(77)91532-X

21. Codaccioni JL, Orgiazzi J, Blanc P, Pugeat M, Roulier R, Carayon P. Lasting remissions in patients treated for Graves' hyperthyroidism with propranolol alone: a pattern of spontaneous evolution of the disease. J Clin Endocrinol Metab. (1988) 67:656-62. doi: 10.1210/jcem-67-4-656

22. Cahoreau C, Klett D, Combarnous Y. Structure-function relationships of glycoprotein hormones and their subunits' ancestors. Front Endocrinol. (2015) 6:26. doi: $10.3389 /$ fendo.2015.00026

Conflict of Interest: The authors declare that the research was conducted in the absence of any commercial or financial relationships that could be construed as a potential conflict of interest.

Copyright (c) $2020 \mathrm{Fu}, \mathrm{Wu}$, Wang and Guan. This is an open-access article distributed under the terms of the Creative Commons Attribution License (CC BY). The use, distribution or reproduction in other forums is permitted, provided the original author(s) and the copyright owner(s) are credited and that the original publication in this journal is cited, in accordance with accepted academic practice. No use, distribution or reproduction is permitted which does not comply with these terms. 